\title{
「ロール」および「関係」に関する基礎的考察に 基づくオントロジー記述環境の開発
}

\section{Development of an Environment for Building Ontologies Based on a Fundamental Consideration of "Role" and "Relationship"}

\author{
古崎 晃司 \\ 大阪大学産業科学研究所 \\ I.S.I.R., Osaka University \\ kozaki@ei.sanken.osaka-u.ac.jp, http://www.ei.sanken.osaka-u.ac.jp/ ^kozaki/ \\ 來村 德信 \\ (同上) \\ kita@ei.sanken.osaka-u.ac.jp, http://www.ei.sanken.osaka-u.ac.jp/〜kita/ \\ 池田 澫 \\ Mitsuru Ikeda \\ (同上) \\ ikeda@ei.sanken.osaka-u.ac.jp, http://www.ei.sanken.osaka-u.ac.jp/members/ikeda/overview.html \\ 溝口 理一郎 \\ (同上) \\ miz@ei.sanken.osaka-u.ac.jp, http://www.ei.sanken.osaka-u.ac.jp/members/miz/
}

keywords: ontology, building ontologies, role, relationship

\section{Summary}

Recently, an ontology is expected to contribute to knowledge sharing and reuse.It is, however, difficult to develop well-organized ontologies because the principles of ontology design are not clear enough. Therefore, a methodology for ontology design and a computer system supporting ontology design are needed. Our research goals include a methodology of ontology design, and development of an environment for building and using ontologies. Building an ontology requires a clear understanding of what can be concepts with what relations to others. An ontology thus focuses on "concepts" themselves rather than "representation" of them. Although several systems for building ontologies have been developed to date, they were not based on enough consideration of an ontological theory. We argue that a fundamental consideration of these ontological theories is needed to develop an environment for developing ontologies. Most of the previous ontologies, which are represented in frame-based languages, don't clearly deal with such concepts that need deep ontological investigation. Therefore we begin with a fundamental consideration of an ontological theory. We discuss mainly "role concept" and "relationship", and consider how these ontologically important concepts should be treated in our environment. On the basis of the consideration we have designed and have developed an environment for building and using ontologies, named "Hozo". This paper presents an outline of the functionality of Hozo. We focus on how it treats the relations and roles on the basis of fundamental consideration.

\section{1.ま え がき}

近年における情報社会の発達は, 知識システムの巨大 化・複雑化を生み出した，光れに伴い情報を単なるデー タや記号として処理する技術にとどまらず，产の情報が 表す内容を知識として扱う必要性が高まりつつある [高岡 95] .このような背景のもと, 知識べースを構筑する際の 背景となるバックボーン情報を提供し，知識の共有・再 利用に貢献するオントロジーに関する研究が盛んになさ れている [溝口 99a]．しかしオントロジーの基礎理論や 構築方法論は未だ十分には確立されておらず, 構築・利 用を支援するシステムの開発や構筑方法論の整備などが 渴望されている.これらの要求に応えるオントロジー構 築・利用環境の開発が本研究の目的である.
従来の知識処理に関する研究の多くが対象とする知識 を「どのように表現するか」という表現形式を重視して いるのに対し, オントロジー研究では対象としている世 界に「何が存在するか」という知識の内容光のものの理 解に重点を置く.よってオントロジー構築の際には, オ ントロジーに現れる基本的な概念を同定する為の基礎理 論が不可欠となる [溝口 99b] . 例えば自転車の部品であ る「車輪」は，注目するコンテクストによって「前輪」や 「操舵輪」といった別の概念として捉えられる .この「車 輪」と「前輪」「操舵輪」の違いは「ロール」に関する 理論で明確な区別がなされる．同樣な例として，「住所」 という概念がコンテクストに応じて「配送先」や「発注 先」など樣々な「ロール」を担う例や，ある「男性」が 
家庭では「父親」, 夫婦間の関係においては「夫」, 職 場では「社員」といった別の「ロール」を果たすといっ た例などがある .このように，知識システムの対象世界 に現れる多くの概念は「ロール概念」で構成されている． しかし，このような概念の峻別をサポートしたオントロ ジー構築環境は未だ開発がなされていない .

弚こで我々は, オントロジー構築に用いられる基本的 な概念についての考察を行い, 得られた知見に基づいて オントロジー構築・利用環境「法造」の設計・開発を進 めてきた [古崎 99a, 古崎 99b] . 本論文ではこれらの成果 を，オントロジー構筑で重要な意味を持つ「ロール」と 「関係」に関する考察内容と，乥れらに基づてて設計・開 発がなされた「法造」の中のオントロジー記述環境を中 心に報告する．

以下，2章では本研究で開発したオントロジー記述環 境の概要を述べる. 続く 3 章では, 本システムの特徵で ある「ロール概念」に関する考察内容とシステムにおけ る実装を述へ，4章では「ロール概念」を導入すること の意義を述べる . 次いで5章では，本システムのもう 1 つの特徵である「関係」に関する基礎的な考察と実装に ついて述べ，6章では関連研究との比較を述べる.最後 にシステムの開発・利用状況と今後の検討課題を述べて 総括する .

\section{2. オントロジー記述環境の概要}

\section{$2 \cdot 1$ オントロジー}

オントロジーとは本来，哲学用語で「存在に関する体 系的な理論」のことをさすが，知識処理の分野では知識 システムを構築する際に用いられる基本概念の体系的記 述をいう.オントロジーにはシステム設計者の視点や利 用目的, 用いられる語彙の意味などの知識ベースを構築 する際の背景情報が明示されている . 知識システムが扱 う対象世界を表すモデルは, オントロジーが提供する規 約の下，概念や関係のインスタンスとして記述される． また対象世界において樣々な一般性を持って成立する問 題解決に用いるルールや制約を，オントロジーが与える 概念や関係の定義に基づいて記述したものを，本論文で は知識と呼ぶ .よってオントロジーに基づき記述された モデルや知識は一貫性を持ち，オントロジーを参照する ことで他人が記述した知識の理解が容易になる .このこ とから，従来システムに暗黙的に埋め込まれていた背景 情報をオントロジーとして抽出し, 光れを明示的に記述 し，弚れに関するある程度の合意を得ることで，知識の 共有・再利用に大きく貢献する .

\section{$2 \cdot 2$ オントロジー構築・利用環境「法造」}

筆者らはオントロジーの基礎理論と構築方法論に関す る考察に基づき, オントロジー構築・利用環境「法造」の 開発を進めてきた [古崎 99a, 古崎 99b] .「法造」とは才

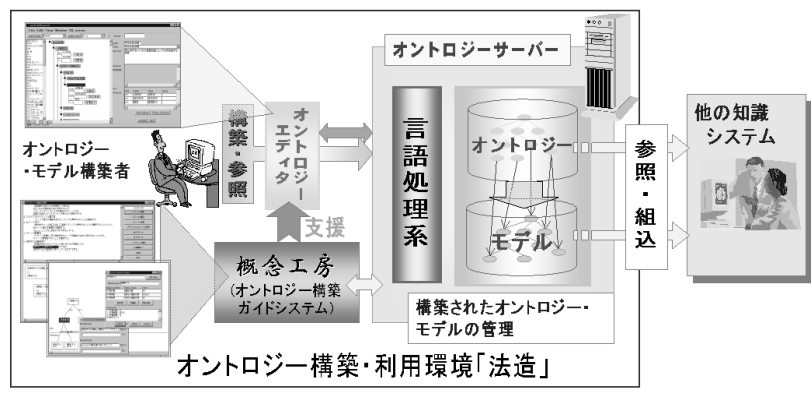

図 1 法造の全体像

ントロジー ( = “法”) を構築する ( = “造”) 計算機環境 で,「オントロジーエディタ」,「概念工房」(オント ロジー構筑ガイドシステム)，「オントロジーサーバー」 から構成される (図 1).

オントロジーエディタはオントロジーの基礎理論に関 する考察に基づて設計がなされた記述環境を提供し (図 2)，オントロジーをグラフィカルに表示・編集する機能 を持つ . 概念間の関係はノード・リンクを用いたグラフ 状に表現され，ユーザーはマウス操作で容易にオントロ ジーの表示・編集を行うことができる．また，概念や関 係の意味定義は専用の画面で表示・編集がなされ，概念 間の関係や意味定義の継承などはシステムが動的に管理 する.この際，形式的な整合性の確認やオントロジーに 基づくモデルの記述機能はオントロジーサーバーとネッ トワークを介した通信を行いながら実行される．

概念工房はオントロジー構築方法 AFM (Activity-First Method) に基づき, 自然言語で書かれたドキュメントか らオントロジーで記述される概念の抽出や組織化を支援 するシステム [久保 98, 久保 99] で, ガイドラインに従 いオントロジーの全体像を構筑することができる . AFM はタスクアクティビティと呼ばれる問題解決の処理を表 す概念を最初に整理し，弚れを基にドメイン概念を抽出・ 整理する構築方法で [Mizoguchi 95, Takaoka 96] , 概念 工房では光の過程を複数のステップに分けて支援する環 境を提供している.AFM および概念工房の詳細に関し ては別稿で報告する [石川 02] .

これらのシステムで構築されたオントロジーやモデル はオントロジーサーバーで管理される.オントロジーサー バーはオントロジーやモデルを管理するために必要な樣々 な機能を持ち，概念の定義，編集，参照，整合性の検証な どのオントロジーやモデルを操作する為の機能が , 操作 関数として整理されている.オントロジーエディタをは じめとする他のシステムとはネットワークを介して接続 されており，これらの操作関数を用いて，オントロジー サーバーが提供する機能を利用することが出来る．構筑 されたオントロジーやモデルは, ユーザー毎に管理され， 必要に応じて外部システムからの参照や, LISP, XML など汎用形式での出力がなされる．

本論文では「法造」の記述環境であるオントロジーェ 
ディタについての詳細を述べる .

\section{2・3「法造」が扱うオントロジー}

オントロジーは対象世界を説明するのに必要な概念と， 乥れらの概念間の関係から構成される.最も基本的な関 係は一般-特殊 (is-a) 関係で, 概念のラベルと is-a 関係 による階層の記述がオントロジーとして最もプリミティ ブなものである．本研究で構築を目指すオントロジーで は，弚れらに意味定義 (制約) や関係の記述 (公理的記 述) を加える . 乥うすることにより，オントロジーはモデ ル構築の際に適切なガイドや示唆を与えることができる．

概念の意味定義は，

・概念名を表すラベル

-上位概念

・自然言語による定義（コメント）

- 部分概念 part-of 関係で表される部分概念

・属性 attribute-of 関係で表される属性

- 公理

から成る . 概念のラベルや自然言語によるコメントは計 算機にとっては意味を持たないが，人間が概念を識別す る際に重要な意味を持つ. 部分概念は光の概念を構成し ている部分にあたる概念で, part-of関係を用いて表現さ れる．属性は概念がもつ性質を表し，attribute-of 関係 を用いて表現する、概念を特徵づける属性には，文字列 や数值で表される属性值にのみならず, 関数としての属 性など樣々な種類のものが考えられるが，法造ではこれ らの属性を区別せずに一括して扱っている．今後, 必要 に応じて属性の種類を詳細化していく. 公理は概念が満 たすべき性質を宣言的に表したもので, 部分概念や属性 に関する制約や関係などか記述される. 部分概念や属性 で表しきれない概念の詳細な意味定義は, 公理を用いて 記述する。

\section{$2 \cdot 4$ オントロジーエディタ}

我々カ開発したオントロジー記述環境であるオントロ ジーエディタは,「ロール」と「関係」に関する基礎的な 考察をシステムに反映させたことを特徵としている．光 れ光れの考察内容とシステムへの実装については3章お よび5章で述べるが，本節ではオントロジーエディタの 基本的な機能について概説する.

オントロジーエディタは，

is-a 階層ブラウザ is-a 階層を表示・編集

Edit Panel is-a 階層ブラウザで選択された概念の定 義内容を表示・編集

Tool Bar 編集のためのボタン類

Menu Bar 各種メニュ一類

の 4 つの部分から構成される (図 2 ) . 以下の節では才 ントロジーエディタの各画面におけるオントロジーの扱 いを述べる。

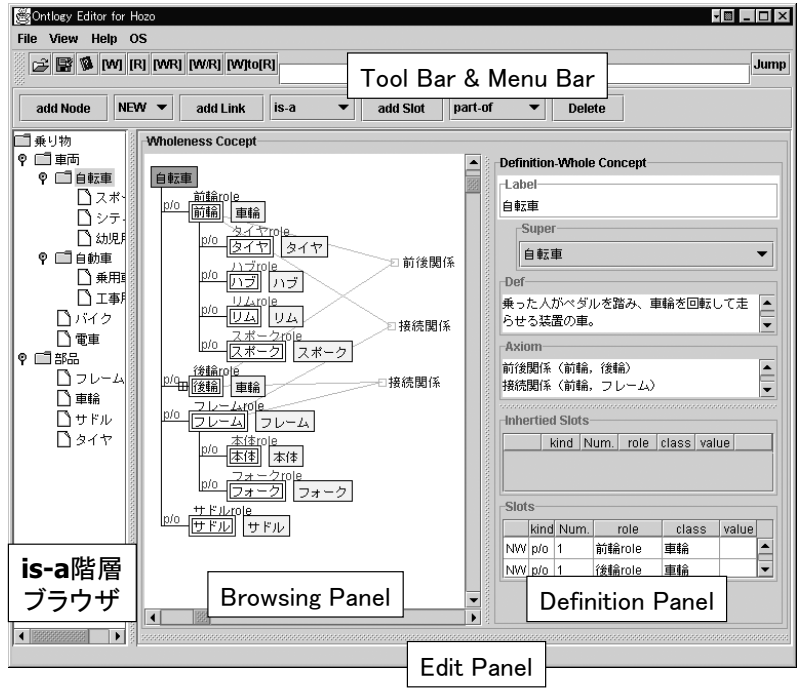

図 2 オントロジーエディタの画面例

\section{$\S 1$ is-a 階層ブラウザ}

is-a 階層ブラウザ (図 2 ) には is-a 階層が Tree 状に 表示され, 各概念が is-a 階層においてどの位置で定義さ れているかを明示する.ママウスで選択がなされた概念の 意味定義は Edit Panel で表示・編集が可能となる . is-a 階層の編集は, Tree 状に表示される is-a 階層に対してマ ウス操作で行い,

・ダブルクリックによる下位ノードの開閉

・ドラッグ\&ドロップによる階層の変更

・編集メニューを用いた产の他の編集操作 などがなされる .

これらの編集操作の結果はシステムが管理し，is-a 階 層の変更による定義内容の継承などの影響は動的に他の 概念へ反映される. 複数の概念から定義内容を継承した 概念の多くは， $3 \cdot 2$ 節で論じるロール概念を用いること で定義することが出来ると考えているので, 本システム では is-a 関係による多重継承は認めていない .

\section{$\S 2$ Edit Panel}

Edit Panel は , is-a 階層ブラウザで選択された概念の 意味定義を表示・編集する. Edit Panel は图 2 に示すよ うに, 弚の概念に含まれる部分概念や属性をグラフィカ ルに表示する Browsing Panel と, 意味定義の詳細を 表示・編集する Definition Panel から構成される .

Browsing Panel は概念や属性を表すノードと概念間 の関係を表すリンクを用いて，概念の意味定義を表示す る.表示方法には part-of 階層を Tree 状に表示する Tree View と，ノードをネットワーク上に自由に配置できる Network View があり, ユーザーはマウス操作と Tool Barや Menu Bar にあるメニュー類を用いて part-of 階 層や属性などの編集を行う．

一方, Definition Panel では Browsing Panel で選択さ れた概念の意味定義の詳細が表示·編集される.Definition Panel に表示される概念定義の内容は， 
a) Browsing Panel で選択中の概念 (クラス) で新た に定義した内容

b）上位概念から継承した定義内容

の2 種類に分かれ , "super” のリストを選択することで 上記の a)，b) の内容を切り替えて表示する . "super” の リストには, 光のクラスの上位概念が全てが一覧できる ように表示され，選択したクラスから継承されている内 容が Definition Panel に表示される .さらに表示中の定 義内容については，

（1）光の概念で新しく追加した定義

（2）上位概念から継承した定義内容を上書きして定義 した内容

(3) 下位概念で定義内容の上書きがなされている内容 に分かれる . これらは表示するフォントや色を変えるこ とで区別される . 定義の上書きをする際には, 上書きし たい定義内容をマウスで選択し, 編集メニューを実行す ることで行う. 㚇の際, 選択していた定義内容は (3) 上 書きされている内容に変わり, 定義を編集中 (Browsing Panel で選択中) の概念に，（２）上書きして定義した 内容が追加される .

\section{$\S 3$ モデルの構築}

本システムでモデルの構築を行う際には, 2 つのウィ ンドウが表示される．1つはクラスを定義しているオン トロジーを参照する為の「オントロジーエディタ」，も う1つはインスタンスを作成するための「モデル (イン スタンス) エディタ」となる.この際システムはクラス を定義しているオントロジーの定義内容を確認し，イン スタンスが作成可能なクラス名のリストを作成・表示す る.ユーザーがリストからクラス名を選択すると, クラ スエディタに選択したクラスの定義が表示され、「インス タンス作成」のボタンを押すことで兴のクラスのインス タンスが作成される．この際インスタンスの定義は，才 ントロジーの定義内容に基づいて記述される .

\section{3. part-of 関係に伴うロール概念}

これ以降，2 章で概要を述べたオントロジーエディタ の2つの特徵である「ロール概念」と「関係概念」に関す る理論的考察を行うと共に, 兴のシステムでの実装につ いて述べる.本章では「ロール概念」に関して , part-of 関係に伴い現れるロール概念を中心に考察し，ロール概 念の理論を導入する意義は次章で述べる．

\section{$3 \cdot 1$ part-of 関 係}

part-of 関係は，ある概念と光の概念を構成している部 分にあたる概念との間の全体-部分関係を表す*1.このと き部分にあたる概念を「部分概念」と呼ぶ .オントロジー

\footnotetext{
*1 [溝口 99b] では 7 種類の part-of 関係の差別化を論じている か現行のシステムでは扱わない . 今後のバージョンで導入する 予定としている.
}

における概念定義 (クラス) 間の part-of 関係は, モデル 構築時に“乥れらのクラスのインスタンス間に, 全体-部 分関係が存在する (可能性がある) こと”を規定してい る。例えば自転車と光の部品である車輪の関係は「車輪 part-of 自転車」と表される．これは “「自転車」と「車 輪」のインスタンス間に全体-部分関係が存在する”すな わち “「自転車」のインスタンスは「車輪」のインスタ ンスを部分として持つ”ことを表す。

part-of 関係について理解を深めるために,「自転車」 と「車輪」の例についてより詳細に検討を進める．先ほ どの例では, 自転車と弚の部品である車輪の関係を「車 輪 part-of 自転車」と表した。一方，自転車の車輪には 「前輪」や「後輪」といったものが存在するので,「前輪 part-of 自転車」と表すこともできる .

ここで “「前輪」と「車輪」には概念的にどの様な違 いがあるのか?"という疑問が生じる .

「前輪」は特定の「車輪」に対する単なる呼び名（ラ ベル) であると考えるかもしれないが「前輪」は「車輪」 に比へてて “前方に取り付けられフォークと接続されてい る”といった概念的情報 (定義) が付加されているので， 「前輪」は単なる「車輪」のラベルではなく「車輪」をよ り詳細化した概念と考えられる．また「前輪」の“進行 方向を決定する機能を果たす”という機能の側面に注目 すると, 同じ「車輪」を「操舵輪」という別の概念とし て捉えることができる

このように, 注目するコンテクストに応じて同じ部品 が別の概念として捉えられる例は多く存在する . 例えば 石油精製プラントにおいて同じ「コントロールバルブ」 が, 注目する属性に忍じて「流量コントロールバルブ」, 「液レベルコントロールバルブ」という異なった呼ばれ 方をする例がある [古崎 02] .このようなコンテクスト に依存して定義される概念は「ロール概念」と呼ばれる [Barwise 83, 溝口 99b] . 次節では, part-of 関係に伴っ て現れるロール概念について述べる．

\section{$3 \cdot 2$ 基本概念・ロール概念・ロールホルダー}

「ロール概念」とは, 「妻としての役割（妻 role)」や 「看護婦としての役割 (看護婦 role)」など, あるものが 特定のコンテクストのもとで果たす役割を捉えて概念化 したものである．弚れに対し「人間」「男性」など他の 概念に依存せずに定義される概念を「基本概念」という． さらに「妻」や「看護婦」など, 基本概念が「ロール概 念」で定義された役割を担った状態を概念化したものを 「ロールホルダー」と呼ぶ . ロール概念には, 概念間の関 係やコンテクストに依存するもの， タスクやドメインに 依存するもの, 人工物におけるロール概念などが存在す ることが知られているが, 本論文では特に part-of 関係 に伴い全体にあたる概念に依存して定まるロール概念に ついて考察する。

部分概念を part-of 関係に伴うロール概念を基に整理 


\begin{tabular}{|c|c|c|}
\hline $\begin{array}{l}\text { ロール概念 } \\
\text { (教師role) }\end{array}$ & $\begin{array}{c}\text { 基本概念 } \\
\text { (人間) }\end{array}$ & $\begin{array}{c}\text { ロールホルダー } \\
\text { (教師) }\end{array}$ \\
\hline [R1] 名前 & [B1]名前 & [R1］名前 \\
\hline \multirow{3}{*}{ [R2-1]年齢（>22） } & [B1]年齢 & [R2-1]年齢（>22） \\
\hline & [B2]身長 & [B2] \\
\hline & [B2]体重 & [B2］体重 \\
\hline \multicolumn{2}{|l|}{ [R2-2]担当教科 } & [R2-2]担当教科 \\
\hline \multicolumn{2}{|c|}{ [R2-2]勤続年数 } & [R2-2]勤続年数 \\
\hline \multicolumn{2}{|c|}{ [R2-2]教職免許を持つ } & [R2-2]教職免許を \\
\hline
\end{tabular}

図 3 部分概念の定義例

すると, 部分概念は下記の3つの概念的要素からなる . ロール概念 全体から見た部分概念の役割を表す概念 クラス制約 ロール概念で定義された役割 (ロール) を 担うものが属すべきクラスに関する制約 . 例えば , 夫 role に対する「男性」など .

ロールホルダー ロール概念で定義された役割を担った 状態の基本概念を表す概念

「クラス制約」はロールを担うことができるもののクラス を制約しており，別の箇所で既に定義された基本概念を 参照している．关の「クラス制約」を満たすものが役割 を担った時「ロールホルダー」となる．例えば「自転車」 の部品である「車輪」が,「自転車」において「前輪として の役割」(前輪 role) や「操舵する役割」(操舵 role) と いったロール概念で定義された役割を果たしている．こ れらの役割を担った「車輪」がロールホルダー「前輪」, 「操舵輪」となる .

ロール概念の定義は, クラス制約で参照している基本 概念の定義内容のうち, 兴の役割を果たすのに必要なも のを参照している .よってこの基本概念の定義内容は，

B1 ロール概念から参照される定義内容

B2 ロール概念から参照されない定義内容

に分かれ，一方，ロール概念の定義内容は

R1 基本概念の定義を参照している内容

R2 ロール概念で追加される定義

R2-1 基本概念から参照した定義内容に制約を追加 したもの

R2-2 基本概念にはない新たな意味定義を追加した もの

に分かれる．

B1 と R1 の定義内容は完全に一致しており，R2-1 は R1 (B1) の定義内容の一部を上書きしている . また ロールホルダーの定義内容は, ロール概念と基本概念の 定義内容を合わせたものとなるので, 上記の R1 (B1)， R2, B2 の和に相当する .

例えば「学校組織」において, 組織の一員として教師と いう役割「(学校組織における) 教師 role」(ロール概念) *2を担った「人間」(基本概念) として定義された「(学

\footnotetext{
$* 2$ 「教師 role」については, 機能 role, 学習者との関係から決 まる role, 職業 role など樣々な定義のされ方が考えられるが， ここでは「学校組織」という全体に当たる概念に依存して定ま
}

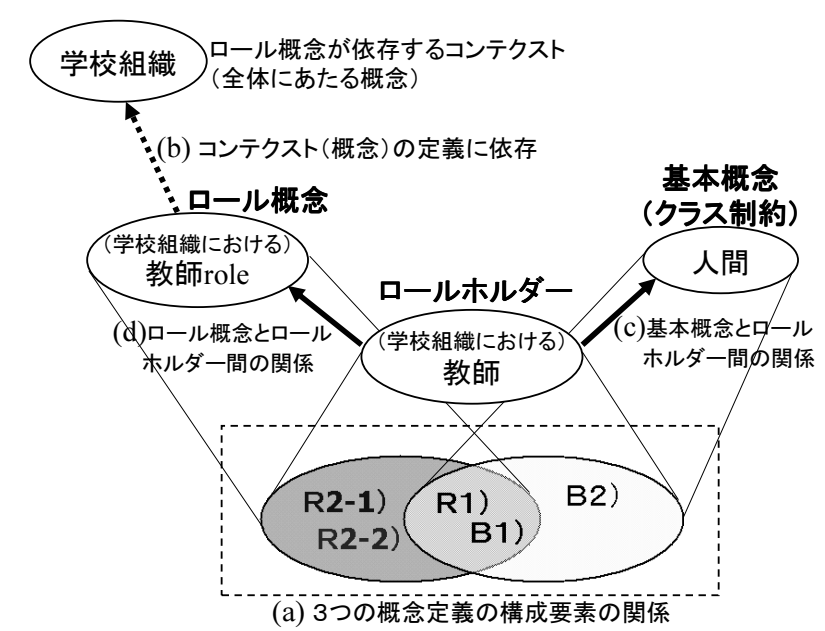

図 4 定義の構成要素間の関係

校組織における) 教師」(ロールホルダー) ${ }^{* 3}$ について考 える (図 3 ) . 例では基本概念「人間」で定義されてい る内容のうち , “教師としての役割”を果たす際に必要と なる「名前」「年齢」が「教師 role」から参照されてい る.ロール概念が参照した定義内容は, ロール概念の定 義内で利用される . 例えば「人間」で定義されている「年 齢」は，「教師 role」で「給与」を計算する際の定義に利 用される.また「年齢」に関しては「22 歳以上」のよ うに, ロール概念の定義内で制約が追加されている .こ れは「教師 role」を担いうる概念が満たすべき制約を表 している。

さらに「教師 role」では “教師としての役割”を果たす ために必要な「担当教科」「勤続年数」「教職免許を持 つ」といった意味定義が追加されている．上記の例では 簡単のため属性のみを定義しているが, 部分概念や公理 など他の定義内容に関しても同樣のことがなされる .

これらの3つの概念の定義の構成要素の関係を, 各概 念定義の構成要素を点とした集合で表すと図 4(a) のよ うになる [林 98] . この図で定義の構成要素の包含関係を 見ると，基本概念「人間」の定義内容がロールホルダー 「教師」に継承されていることが分かる．これは形式的に は is-a 関係における継承と同じに見えるが , 概念的な性 質が異なる．これについては 4 章で詳しく述べる .

\section{$3 \cdot 3$ part-of 階 層}

部分概念は光れ自身が別の概念を部分概念としてもつ. 例えば「自転車」，「車輪」が図 5 のように定義されてい たとすると、自転車」の部分概念「前輪」はクラス制約 で参照している「車輪」から部分概念「スポーク」「タ イヤ」,「タイヤチューブ」,「リム」を継承し , 図 5 のよ うな part-of 階層が形成される .

ここで注意すべきは， $3 \cdot 2$ 節の考察により，

る (図 4(b)) ロール概念と見なす。

$* 3$ 以下, 単に“教師 role”および“教師”と記述する。 


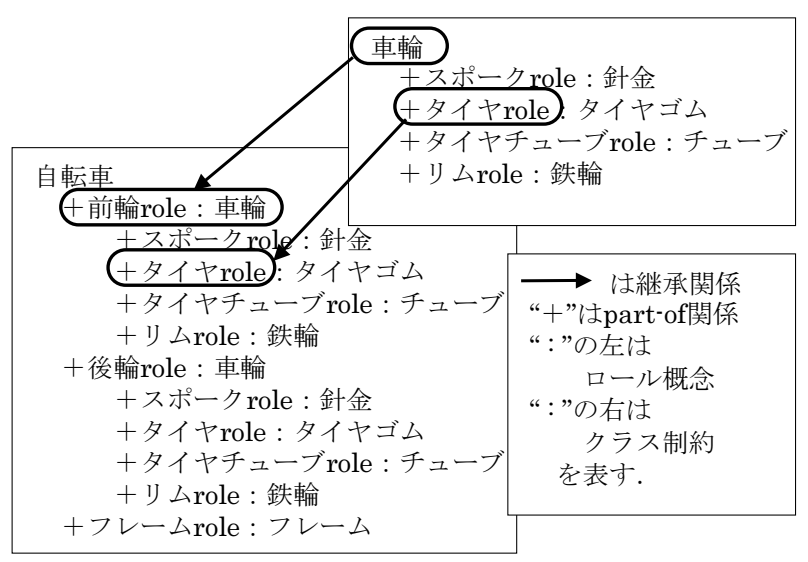

図 5 part-of 階層の例

-「自転車の前輪」の定義は「車輪」の定義内容を継 承している ことと ,

-「車輪のタイヤ role」と「自転車の前輪のタイヤ role」 が概念的に異なり「自転車の前輪のタイヤ role」が 「車輪のタイヤ role 」の定義内容を継承している という関係になることである.この為「前輪」の部分概 念である「タイヤ」の意味定義の変更をサポートするた めには，下記の3つの場合について対処する必要がある

（1）クラス制約が参照している基本概念「タイヤゴム」 を変更

変更の影響は「タイヤゴム」の定義を参照している 全ての箇所（例では,「車輪」「前輪」,「後輪」) に影 響する。

(2)「自転車の前輪のタイヤ role」の上位にあたるロー ル概念「車輪のタイヤ role」を変更

「車輪」の定義を継承している箇所に影響する．上 記の例では「自転車」の「前輪」と「後輪」の両方 の定義に変更が伝播される.

(3) ロール概念「自転車の前輪のタイヤ role」を変更 「自転車の前輪」の定義のみが変更され「車輪」や 「タイヤゴム」の定義には変更が影響しない．

\section{$3 \cdot 4$ 部 分 概 念の 数}

ある概念は同じ部分概念を複数持つことがあり，下記 の3つ場合が考えられる .

(1) 部分概念の数が不特定多数 (例) 木の葉

(2) 部分概念の数が特定多数 例) 車輪

(3) 部分概念の順番を問題にする 例) 入賞者

(1) の場合は複数の部分概念を同じものが多数集まって いると見なし, 部分概念の数や個々の違いを問題としな い.一方，(2)では「店」における「客」のように部分概 念の数が決まっていなくても，1つ1つは同じ種類の別 の概念として扱われる.オントロジーエディタでは，(1) の不特定多数を “*”，(2) の特定多数を “n”，(3) の順番

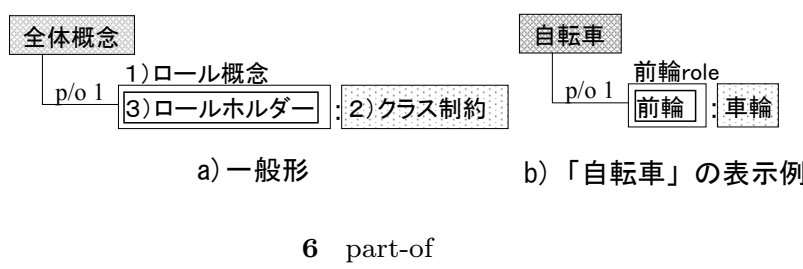

を問題にする場合を“@n”で表記する.(n は自然数，ま たは「客」のように数が決まっていないことを表す際に は “N” が入る .) これらの部分概念の数は，下位概念に 意味定義が継承されるときや，モデルを構築する際の制 約として利用される。

\section{$3 \cdot 5$ 記述環境における part-of 関係の扱い}

本節ではこれまでの考察を基に, part-of 関係および光 れに伴う諸概念のオントロジーエディタにおける扱いに ついて述べる。

図 6 に Browsing Panel における part-of 関係と光れ に伴うロール概念の表示例を示す . 部分概念を表すノー

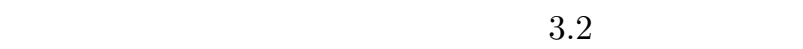
ロール概念， 2 ) クラス制約，3 ) ロールホルダーを表 している .ロール概念は白いノードで表され，上部には ロール名が表示される．弚の右側のノードはクラス制約 を表し，全体概念 (基本概念) を表すノードとの網掛け の違いで他の箇所でなされている概念定義を参照してい ることを示している．ロールホルダーはロール概念を表 すノードの内部に入ったノードで表されている.例では， クラス制約で参照している「車輪」がロール概念「前輪 role」を担ったロールホルダーが「前輪」であることを示 している .ロール概念ノードをつなぐ part-of/attributeof リンクには,リンクの種類を表すラベル (part-of なら "p/o", attribute-of なら “a/o") と，部分 (属性) の数 に関する制約を示す数字や記号が記される。

ノードをマウスで選択すると, 意味定義の詳細が Definition Panel に表示され編集が可能となる . Definition Panel は, 基本概念用と部分概念用の 2 種類があり，選択 した概念の種類によって自動的に切り替わる . 基本概念用 については $2 \cdot 3$ 節で述べた意味定義が表示される.一方， 部分概念用の Definition Panel では, 画面の上部にロール 概念名 (role-concept)，クラス制約 (class-constraint)， ロールホルダー名 (role-holder) が表示され, 画面の下 部は part-of 関係に伴う諸概念の定義を表示・編集する 為に，以下の3つの View をタブで切り替える (図 7). Part View ロール概念の定義内容を表示・編集する． ここで可能な編集操作は「新たな定義の追加」と「基 本概念から参照している定義への制約の追加」の2 つである。

Basic View クラス制約で参照している基本概念の定 義内容を表示する．このView では定義内容を編集 することはできず,「ロール概念から参照する/しな 


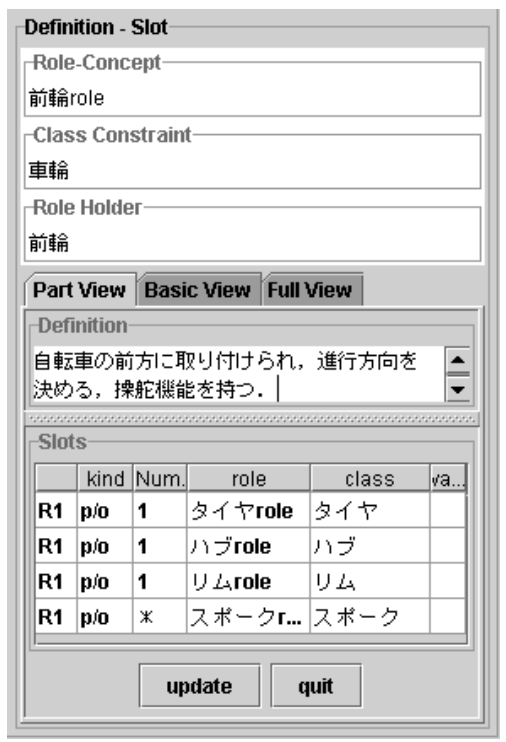

図 7 Definition Panel (部分概念用)

い」の設定のみ変更できる .

Full View ロールホルダーの定義内容を表示する.こ のView は , 定義内容を表示するのみで編集はでき ない。

上記から分かるように, 部分概念の定義内容の編集は, Basic View でロール概念が参照する概念の定義内容を設 定し，Part View でロール概念の定義を編集するという 手順で行われる .

なおこれらの View は Browsing Panel におけるロー ル概念ノードで，1 ）ロール概念，2）クラス制約， 3 )

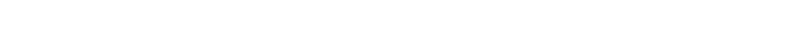
のノードをクリックした際にも切り替わる .

また $3 \cdot 3$ 節で述べたように , part-of 階層において部分 概念の定義を変更する際には，

（1）クラス制約が参照している基本概念の定義を変更 する

（2）選択中のロール概念の上位にあたるロール概念の 定義を変更する

（3）選択中のロール概念の定義を変更する

\section{の3 種類の場合がある .}

Browsing Panel でロール概念ノードを選択した場合 にDefinition Panel に表示されるのは, 上記 (3) の意味 定義であるが，メニューを選択することで (1)，(2) の概 念定義にジャンプすることができる .この際，行き先に 応じて is-a 階層ブラウザおよび Browsing Panel におけ る編集する概念の選択状態が切り替わり，乥こで定義内 容を編集した際の影響の伝播はシステムが自動的に管理 する．

\section{4. ロール概念導入の意義}

3 章では基本概念の他に , ロール概念とロールホルダー という 2 種類の概念を導入した .我々がこのような概念を 導入したのは, これらの概念の性質が基本概念と異なり， 乥の違いを明らかにして3つの概念を峻別することが， オントロジーを構築する上で重要と考えるからである．

本章では, 基本概念とロール概念およびロールホルダー の概念的な性質の違いを明らかにすると共に，ロール概 念を導入することて解決できる問題を挙げ，これら 3 種 類の概念を峻別する意義を述べる .

\section{$4 \cdot 1$ ロール概念の性質}

ここではロール概念やロールホルダーの特徵の1つと して，インスタンスが具体化される際の性質を述べる.な お簡単の為に , ここでは identity の認定などインスタン スに関する厳密な議論 [溝口 99b] は行わない .

性質1ロール概念のインスタンスの2 種類の状態 ロール概念のインスタンスに相当するものは，光 の概念的な性質から次の $2 つ$ つ状態が存在する .

(1) ロール概念で定義された役割のみが具体化さ れ，弚の役割を担うインスタンスがまだ存在し ない状態 $\left(\mathrm{Ri}^{\prime}\right)$

(2) 具体化された役割が, 特定のインスタンスに よって担われた状態 (Ri)

性質2 ロール概念のインスタンスのコンテクスト依存性 基本概念が他の概念に依存せずに定義されるのに 対し, ロール概念は特定のコンテクストや他の概念 に依存して定義される . part-of 関係に伴うロール 概念の場合は, 部分概念を構成している全体にあた る概念がロール概念の依存しているコンテクストと なる.よってロール概念のインスタンス Ri' は, 光 のロール概念が依存している全体にあたる概念のイ ンスタンス (Wi) の存在を前提として具体化され， Wi が消滅すると光れに伴って Ri' も消滅する. $3 \cdot 2$ 節の例では, ロール概念「(学校組織における) 教師 role」は「学校組織」というコンテクスト (全体に あたる概念) に依存して定義されている (図 4(b)) . この「教師 role」の Ri' (「教師 role $\left.\left(\mathrm{Ri}^{\prime}{ }^{\prime}\right)\right\lrcorner$ ) は,「学 校組織」のインスタンス「学校組織 $(\mathrm{Wi})\lrcorner$ の存在 を前提として定義される.よって「学校組織 $(\mathrm{Wi})\lrcorner$ か溌校になるなどして消滅すると, 弚れに伴い「教 師 role(Ri')」も消滅する.なお「学校組織 $(\mathrm{Wi})\lrcorner$ が 存続していても，「学校組織 $(\mathrm{Wi})\lrcorner$ の定義が変更さ れ，例えば教師の人員が削減されるなどして，「教師 role $\left.\left(\mathrm{Ri}^{\prime}\right)\right\lrcorner$ のみが消滅する場合もある .

性質3 ロール概念のインスタンスの基本概念への依存性 Ri'は光のままでは完全なインスタンスとしては 振る舞うことができない. 例えば「教師 role ( $\left.\mathrm{Ri}^{\prime}\right) 」$ は「担当教科」「給与」など「教師 role」で定義され 
た属性は持つが, この役割を担う「人間」のインスタ ンスが決定するまでは, 全ての属性値を決定するこ とは出来ない、特定の基本概念のインスタンス ( $\mathrm{Bi})$ によって Ri' の役割が担われると，Ri' はロール概念 の完全なインスタンス $(\mathrm{Ri})$ となる .この時, 基本 概念のインスタンス (Bi) が役割 (Ri') を担った状 態がロールホルダーのインスタンスに相当するもの (RHi) となる，逆に，Bi が光の役割を担うことを 止めると，Ri は Ri'に戻る . 例えば,「人間」のイン スタンス「山田氏」が「教師 role ( $\left.\left.\mathrm{Ri}^{\prime}\right)\right\lrcorner$ の役割を 担うと,「教師 role $\left.\left(\mathrm{Ri}^{\prime}\right)\right\lrcorner$ はロール概念のインスタ ンス「教師 role (Ri)」となり，「山田氏」は「教師 (RHi)」となる .この「山田氏」が退職するなどし て「教師 (RHi)」をやめると，「教師 role (Ri)」は 空きポス卜「教師 role $\left.\left(\mathrm{Ri}^{\prime}\right)\right\lrcorner$ に戻る .

性質4 ロールホルダーの具体化・消滅の性質

先に述べたようにロールホルダーのインスタンス (RHi) は基本概念のインスタンス $(\mathrm{Bi})$ と, $\mathrm{Bi}$ が Ri' の役割を担うことで生じたロール概念のインス タンス (Ri) を合わせたものである.よってロール ホルダーを具体化するには Bi と Ri' の存在が前提と なり，単独で具体化することはできない．

このような RHi と Bi と Ri の関係から, RHi が 消滅する際には以下の 3 通りの場合がある .

(1) Bi が消滅する：このとき，RHi も無くなり， Ri は Ri' に戻る . 例えば，山田氏が死んで「人 間」のインスタンス (Bi) で無くなると「教師 $(\mathrm{RHi})\lrcorner も$ 無くなり，「教師 role (Ri)」は空き ポス卜「教師 role $\left.\left(\mathrm{Ri}^{\prime}\right)\right\lrcorner$ となる .

(2) Ri'が消滅する：このとき，RHi も無くなる がBi は炎のまま存続する.例えば, 学校が廃校 になるか教師の枠が削減され「教師 role (Ri')」 が無くなると、教師 $(\mathrm{RHi}) 」 も$ 無くなるが「人 間」のインスタンス (Bi) としての山田氏は光 のまま存続する .

(3) $\mathrm{Bi}$ が Ri' の役割を担うことを止める : このと き,Ri はRi'に戻るのでRHi も無くなるが, Bi は光のまま存続する . 例えば, 山田氏が退職し 「教師 role（Ri')」の役割を担うことをやめる と「教師 (RHi)」も無くなり「教師 role (Ri)」 は空きポスト「教師 role ( $\left.\mathrm{Ri}^{\prime}\right) 」 に$ 戻るが ,「人 間」のインスタンス (Bi) としての山田氏は存 続する．

\section{$4 \cdot 2$ 基本概念・ロール概念とロールホルダーの関係}

$3 \cdot 2$ 節で述べたように, ロールホルダーと基本概念間 の関係 (図 4(c)) および，ロールホルダーとロール概念 間の関係 (図 4(d)) は,一見, is-a 関係による多重継承 に見える．しかし前節で述べた概念的な性質の違いから， 乥れらの間の関係を単なる is-a 関係で組織化することは
適切ではない，本節では光の理由についてより詳しく述 ベる .

まずロールホルダーと基本概念の関係 (図 4(c)) を， 「ロールホルダー is-a 基本概念」と組織化した場合の問 題点について述べる.例えばロールホルダー「教師」が 山田氏 instance-of 教師 ； 教師 is-a 人間 のように表現された場合を考える

この場合，山田氏が教師を辞めたとすると，光れは“ 教師インスタンスの消滅”に対応する ${ }^{* 4}$. しかし，この 組織化では, 教師インスタンスは人間インスタンスでも あるため，退職によって “教師インスタンスが消滅”する と，“人間インスタンスも消滅”（すなわち人間の死亡を 意味) することになる .このことから上記のモデル化は， 現実世界を正しくモデル化していないことが分かる．

続いて, ロールホルダーとロール概念間の関係 (図 4(d)) を「ロールホルダー is-a ロール概念」とした場合 における問題を述べる．例えば，is-a 関係の常識的な理 解から「商品にはリンゴやミカン, 車, 本など多くのも のがある*5」のように考えて，

あるリンゴ instance-of 商品としてのリンゴ

； 商品としてのリンゴ is-a 商品（商品 role） のように商品を is-a 関係の上位に置く場合がある．

この場合に「(商品としての) リンゴ」のインスタン ス (であるリンゴ) は「商品 role」のインスタンスでも ある「商品としてのリンゴ」インスタンスは傷が入った り，污れたりすると商品としての価値が失われ商品では なくなるが, 光のことは1つの商品 roleのインスタンス の消滅を意味する．しかし，乥れはリンゴであることに は変わりはなく, リンゴのインスタンスとしては存続す べきである.従って1つのインスタンスについて破棄と 存続という矛盾する要求が生じるという不都合が生じる.

上記の 2 つの問題は, is-a 関係にある 2 つの概念 $\mathrm{A}$ ， B があり ( A is-a B) , x が A のインスタンスであれ ば ( $\mathrm{x}$ instance-of $\mathrm{A})$ 弚れは $\mathrm{B}$ のインスタンスでもある こと (x instance-of B) から当然と言える結果である. ここで is-a と instance-of 関係というのはものの存在を 規定する重い関係であるのに対し，ロールにはインスタ ンスの存在を支持するだけの「強さ」がない為に, 上述 のような問題が生じる．よって，ロールに関わる概念関 係に is-a や instance-of は使うべきでないことが分かる . このような is-a 関係の誤用の問題を，Guarino は is-a overloading と指摘して 4 種類に分類しており [Guarino 98]，上記で述べたロール概念に関わる問題については "suspect type-to-role link"と呼んでいる.

なお，これらの問題は，従来の枠組みに外付けの一貫 性維持手続きを工夫すれば，回避することは可能である

\footnotetext{
*4 ここでは “元教師”といつた属性などを用いる組織化につい ては考えない

*5 ここでの商品はロール概念である商品 role であり, リンゴ， ミカン , 車 , 本は, 商品 role を担ったロールホルダーである
} 
と考えられる．しかし，弚のようなアドホックな対処法 は，暗黙の状況に応じて言語のセマンティックス (この 例では instance-of 関係の意味の解釈) が変化すること を許すことになり，光れは知識べースの再利用性低下や， メンテナンスのコスト増大などの大きな一因となる .こ のようなアドホックな対処法における問題点は，これま でのエキスパートシステムやソフトウェア構筑の研究に おいても指摘されている．弚れに対して本論文では，上 述のようなロール概念に関するインスタンスの存在の特 性を，ロール概念の性質として明確にした . 光して，光 のロール概念を用いることで , 例で示したような問題を 一般的な枠組みで扱うことが出来るようになった 。

\section{$4 \cdot 3$ 複数のロールを担う概念}

ロール概念の特徵の1つとして，ある概念のインスタ ンスがコンテクストに応じて複数の異なるロールを担う ことがある.例えば, 学校においては「教師」であり，夫 婦においては「夫」である「人間」のインスタンス「山 田氏」について検討する .

従来の is-a 関係を用いると、「教師」と「夫」を is-a 関 係によって多重継承した「教師 +夫」クラスを作成し，光 のインスタンスが「山田氏」であると捉えることが出来 るが , このような組織化の問題点は前節で述べた通りで ある

このような複数のロールを担う概念もロール概念を導 入することで,「山田氏」は基本概念「人間」のインスタ ンスであり，「山田氏」がロール概念「教師 role」および 「夫 role」を同時に担って，ロールホルダー「教師」およ び「夫」となったと表すことができる．ここに現れる「人 間」「教師 role」「夫 role」「教師」「夫」といった諸々 の概念定義の関係は， $3 \cdot 2$ 節で述べた枠組みで明示され る．また「山田氏」が「教師」を退職した場合や，更に 「山田氏」が仕事後に通っている英会話学校では「生徒」 となるといったコンテクストに応じた変化の樣子につい ても，前項で述べたロールホルダーの性質により一般的 な枠組みで自然に扱うことが出来る。

\section{5. 関 係 概 念}

本章では我々が開発したオントロジーエディタのもう $1 つ$ 特徵である「関係概念」に関する考察と，システ ムでの実装を述べる .

\section{$5 \cdot 1$ 関係概念と 全体概念}

あるものを記述する際には 2 通りのとらえ方ができる . 例えば夫婦を概念化するときに，「山田さん夫婦」といっ た場合には夫婦を 2 人から構成される概念としてとらえ ているが、、太郎と花子は夫婦だ」といったときには 2 人 の間に成り立つ関係としてとらえている .
基本的にはすべてのものには概念と関係としての両方 とらえ方が存在する．例えば「自転車」を構成する部品 間の関係を「自転車関係」として概念化することや，「接 続関係」にある複数の部品を「接続関係物」といった概 念としてとらえることも原理的には可能である．これら の概念化の強調のされ方は概念の特性によって異なり，

(1) 主に概念としてとらえられる例：自転車

(2) 概念・関係の両方としてとらえられる例 : 夫婦/夫 婦関係

(3) 主に関係としてとらえられる例：前後関係

がある.しかし，このような概念化のされ方をサポート するオントロジーの記述環境は見られない．本研究では これらのとらえ方に関して，「 全体概念」，「関係概念」 という2つの概念を導入する. 全体概念とは，あるもの を光の一部分をなす複数の概念から構成される全体とし てとらえ概念化したものであり，関係概念とは，複数の概 念間に成り立つ関係を概念化したものをいう [溝口 99b] . 先ほどの夫婦の例では, 前者が全体概念の「夫婦」であ り，後者か関係概念「夫婦関係」として “夫婦”を概念化 したものにあたる .

全体概念は構成要素となる概念 (部分概念) を含み, 部 分概念との間には part-of 関係をもつ.よって $3 \cdot 2$ 節で 述べたように part-of 関係に伴いロール概念，クラス制 約，ロールホルダーの3つ概念要素か現れる. 弚れに対 し関係概念は，概念間の関係を概念化したもので，弚の 関係に参加する概念 (参加概念と呼ゔ) は関係概念の概 念定義には含まれない . 参加概念は 3 章で述べた部分概 念と同じ枠組みで定義され，参加概念に数に関する制約 や参加概念間の公理も定義することができる．

関係概念は他の概念を定義する際には，“部分概念の インスタンス間にある関係が成り立つ”という概念間の 関係に関する制約の記述に利用される，光の際ある1つ の概念が，全体概念に基づくロール概念と，公理に記述 された関係概念から決まるロール概念の複数のロール概 念を持つことがある．例えば全体概念「家族」を考える． ここでは簡単のため，両親と子供から構成される “完全 な核家族”について考えると，「家族」は，父親としての 役割（「父親 role」）を持った「男性」，母親としての役 割（「母親 role」）を持った「女性」，子供としての役割 (「子供 role」) を持った「人間」から構成される全体概 念として記述することが出来る．この家族における「父 親」と「母親」の間には “「夫婦関係」が成り立つ”と いう関係に関する公理を記述することができる．このと き「家族」において「父親 role」を担う「男性」はこの $\ulcorner 夫$ 婦関係」における夫としての役割 (「夫 role」) とい うロール概念もあわせて持つことになる．さらに「父親」 と「子供」の間に「親子関係」を記述すると，兴の「男 性」は「親子関係」における親としての役割 (「親 role」) も持つことになる、構筑・利用環境では，このような公 理における関係概念の利用や，複数のロール概念を持つ 


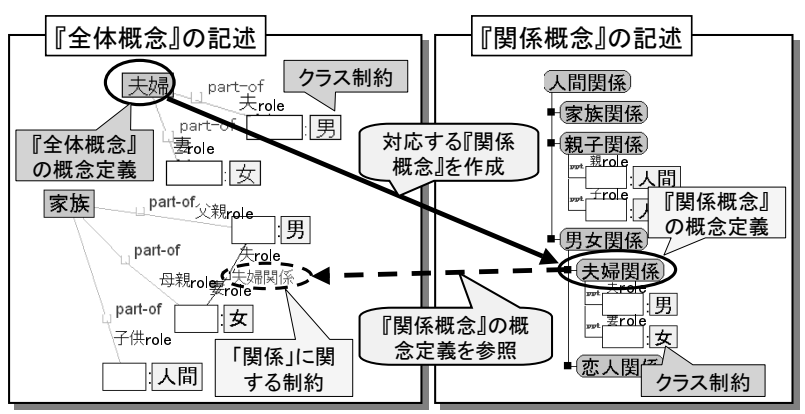

図 8 「関係概念」の記述例

概念の扱いを検討する必要がある .

\section{$5 \cdot 2$ 記述環境における 関係概念の扱い}

前節の考察からオントロジー構築・利用環境では、全 体概念」・関係概念」および光れらの対応をシステムが 保持し , 必要に応じて表示せねばならないことが分かる。 概念定義の表示・編集については，「全体概念」・「関係概 念」の炎れ光れに専用のウィンドウを用意し，乥れらの 対応関係はシステムが管理する .

ここでは実際のシステムで「全体概念」および「関係 概念」がどのように記述されるかを，5・1 節で述べた例 の記述方法を通して概説する.図 8 は, 左が全体概念， 右か関係概念を記述する画面を表わしている．

（1）「夫婦」を「全体概念」として記述する .(この際 に「夫 role」「妻 role」も定義する)

（2）「夫婦」の概念定義を示すノードを選択し，“対応 する関係概念の作成”メニューを実行する．

(3) 関係概念の記述画面に「夫婦関係」が半自動的に 作成され，同時に(1)で作成した「夫 role」「妻 role」 を共有 (再利用) することで「夫婦関係」における $\ulcorner 夫$ role」，「妻 role」が作成 (定義) される*6.

（4）次に別の全体概念として「父親」，「母親」，「子供」 から構成される「家族」という概念を記述する．

（5）「家族」における部分概念「父親」と「母親」を 選択し，Tool Bar の “関係の種類”で「夫婦関係」 を選び，“関係の追加”を実行する .ここで追加され る関係は , 関係概念として定義に従って追加できる 関係の種類などの制約を受ける .

(6)「家族」の定義に，“「父親」と「母親」の間には 「夫婦関係」がある”という公理が追加される．

（7）この時「夫婦関係」の概念定義が参照され「家族」 において「父親」となる「男性」と「母親」となる 「女性」は，乥れ午れ「夫 role」と「妻 role」も担う ことになる .

(8) Definition Panel を用いて部分概念の各ロール概 念の定義を編集する .

*6 ここでは全体概念を先に定義しているが，関係概念を先に定 義した場合にも同樣のことがなされる .
$5 \cdot 1$ 節で述べたように，全体概念「夫婦」および関係 概念「夫婦関係」から定まるロール概念は相互に対応し ている．弚のロール概念を「家族」の定義で参照してい るので, 上記の (1)(3)(7) に現れる「夫 role」,「妻 role」 は同一の定義内容となるようシステムで管理される．ま た「家族」において「父親」となりうる「男性」のよう に複数のロール概念を持つ部分概念の Definition Panel では，弚の基本概念 (ここでは「男性」) が担いうるロー ルの一覧を表示し，編集する定義内容を選択することが できる .

\section{6. 関連研究との比較}

オントロジー記述環境に関してはいくつかの開発例が 存在する . Stanford 大学の KSL はネットワークを用いて オントロジーの共同構築・共有を图るシステムを稼働させ ている [Farquhar 96] .このシステムでは, オントロジー 記述言語 Ontolingua で書かれたオントロジーの表示・編 集が可能で , 既に公開されているオントロジーを拡張した り，弚の一部を利用してオントロジーを構築することがで きる.Swartout らは，汎用な大規模オントロジーを用い て ,ドメインオントロジーを構筑するための Web ベース のツール Ontosaurus を開発している [Swartout 96] . ま た, Karlsruhe 大学 AIFB 研究所の OntEdit[Staab 00] や Stanford 大学の Protégé[Noy 01], Mahalingam ら の Java Ontology Editor (JOE) [Mahalingam 99] や Domingue らの WebOnto[Domingue 98] などはともに Java 言語を用いて開発されたオントロジーの記述環境で， ネット上で公開されている.一方, 武田らの Designers amplifier は共有オントロジーの構築を目指したシステム で，オントロジーの記述環境が含まれる[鷹合 97] .これ らのシステムに共通する限界は従来の知識表現言語の域 を出ていないこと，言い換えれば，オントロジーが持つ 本質的な特性を扱う能力が十分では無いことである.

具体的には「法造」のオントロジーエディタには，こ れらのシステムと比較して以下のような特徵があり，

（1）基本概念，ロール概念，ロールホルダーの峻別

(2) 関係概念と全体概念の対応の明示化と管理 本格的なオントロジー記述を可能にするシステムである．

(1) の 3 つの概念を峻別することの意義は $4 \cdot 1$ 節で述 ベた通りである . 既存システムの中にも，ロールという 概念が用いられているものがあるが [Farquhar 96]，乥れ らの多くは, 関係の両端にくる概念の呼び名やスロット のことを「ロール」と呼んでいるのみで, 単なるラベル付 け以上にロールの定義を記述可能な環境は少ない .ロー ルの定義を記述する枠組みを提供している環境としては， OntoEdit[Staab 00] や Protégé[Noy 01] などがあるが， これらのシステムではロール概念とロールホルダーは区 別されておらず，ロールを担う基本概念の定義と，ロー ルの定義がどのような関係にあるのかが明確になってい 
ない、また, $3 \cdot 2$ 節で述べた $\mathrm{R} 2$ に当たるロール概念独 自の定義を追加することは出来ない．

本論文で導入したロールは，これらのシステムに比べ て，ロール概念とロールホルダーを峻別した上で，ロー ル概念独自の定義を記述し，兴のロールを担う基本概念 の定義との関係を明確にしている点が大きく異なる . こ のようにロール概念の定義を独立させ, $3 \cdot 2$ 節で述べた ように , 基本概念・ロール概念・ロールホルダーの3つの 概念を峻別し，弚れらの定義内容の関係を明確に扱う枠 組みを提供することで，ロールの生成/消滅などに伴う 概念定義の变化の伝播を，汎用な枠組みで明示的に扱う ことが出来る．さらにロール概念の定義を明確にするこ とで, 樣々なロール概念の概念的な違いが明らかになり， 同じラベルで呼ばれる類似したロール概念の本質的な相 違点を明示することが出来る．例えば「教師 role」は「学 校組織」というコンテクストに依存して定まるロール概 念である「(学校組織における) 教師 role」のほかに「職 業」というコンテクストからみた $「$ (職業としての) 教 師 role」や，教える」という行為に依存して決まる「(教 える行為における) 教師 role」など，樣々な「教師 role」 を考えることが出来る .これら複数の「教師 role」の概 念的な違いは，本論文で導入したロール概念定義の枠組 みによって明確に表すことができ，ロール概念の組織化 がなされオントロジーの再利用性向上に貢献する .

知識システムか対象とする世界には樣々な種類のロー ル概念力現れるので, ロール概念の組織化はオントロジー 構築において重要な意味を持ち, 今後の研究課題の1つ として検討を進めている．なお，樣々な種類のロール概 念の分類やロール概念の同定に関する研究成果は「法造」 のオントロジー構築ガイドシステムである「概念工房」 に反映されており別稿て報告する [石川 02] .

さらに (2) の関係概念を用いるとロール概念間の関係 を記述することが出来る．例えば， $5 \cdot 2$ 節で述べた「核 家族」における「父親 role」を担う男性は，「母親」との 間に「夫婦関係」があり，兴の「夫婦関係」から定まる $\left\ulcorner\right.$ 夫 role」も同時に担う ${ }^{* 7}$. こことから「父親 role」は 「夫 role」の定義に依存していることが分かる .このよう なロール概念間の関係は，先に述べたロール概念の組織 化に用いられる .

既存システムにおいては関係の定義について詳細な記 述を行える環境は少ない. OntoEdit などのいくつかの 環境では，関係の定義を is-a 関係を用いて階層化する枠 組みを提供しているが，主に 2 項間関係の記述が中心と なっている．また，関係に依存して定まるロール概念を 扱う枠組みが前述の通り十分ではないので, 本論文で述 べたような複雑な関係を記述するには適していない．こ れらのシステムに比べて，本システムでは (全体) 概念 と同じ枠組みで関係の定義を行うことができ，複雑な関 係についてはロール概念間の関係を用いることで , 別の

$* 7$ ここでは私生児に関しては考えない .
基本的な関係との組み合わせで比較的容易に記述するこ とが出来る。

このように 「法造」のオントロジーエディタでは，既 存のオントロジー記述環境で扱うことが出来なかった概 念的な性質を，ロール概念を中心とした統一的な枠組み で明示的に扱うことが出来る。これはオントロジーを構 築するユーザーにとって，オントロジー構築時に混同し がちな概念の相違点を明確にする，一種の概念化の指針 を提供することになる．また，このような統一した枠組 みに従ってオントロジーを構築することで, 構築したオ ントロジーやモデルの再利用生を高めることに貢献する .

\section{7. 開発·利用状況}

本論文で述べたオントロジーエディタの前身は Java 言語を用いたネットワークベースのアプリケーションと して開発がなされ，約 4 年間に渡り研究室内外の樣々な プロジェクトで実際に使用され，高い評価を得ている 具体的には，知的教育システムのオントロジー [金 99]， CSCL におけるシステムのインタラクションオントロジー [Barros 01] などの構築に利用がなされてきた .さらに 本論文の考察内容から得られた知見と，これまでの利用 者から得られた意見に基づいて開発がなされたオントロ ジーエディタの最新版は, 既に研究室内での利用がなさ れており，並行して開発が進められているオントロジー サーバーと合わせて一般公開する準備が整っている．

このような構築環境の評価は, 従来システムに比べた 質的な新規性と，システムの使用した評価からなされる . 本システムの新規性については前章で述べた通りである． 一方 , システムを使用した上での有用性の評価は長期間 の使用経験によって示されることが多い為，客観的な評 価は一般的に難しい. しかし, システムを複数のオント ロジー構築に利用することで, ある程度の評価を得るこ とができると考えられる . 前述のように , 本システムは 現在, 研究室内の複数のプロジェクトにおいてオントロ ジー・モデルの構築に利用され，実際のオントロジー構 築に必要な機能力提供されていることか確認されている。 これらの利用例を通して得られた成果の一例を示すと， 旧通産省の支援のもと，ヒューマンメディアプロジェク 卜の一環としてなされた，石油精製プラントのオントロ ジーと対象モデル [佐野 99] の構筑がある.この際，構筑 された概念数約 400 のプラントオントロジーおよび部品 数約 2000 というプラントモデルは, 企業の専門家から も現実の石油精製プラントを扱うのに十分な規模を提供 していると認められており，本システムか現実規模の才 ントロジーの構築に十分耐えうるシステムであることが 示されたと言える.さらに同プロジェクト内の開発シス テム (三菱電機 (株) , 日石三菱石油 (株) が参加) に おいて，これらのプラントオントロジーおよびモデルを 利用したアプリケーションも開発され，オントロジーエ 
ディタがオントロジーの構築から利用までの一連の過程 をサポートできることが示された .この詳細は別稿で報 告する [古崎 02$]$. また , 機能オントロジーの構築 [來村 02]においては, 従来の記述環境では構築が困難であっ たオントロジーの構築が可能となったとの評価を受けて いる .

\section{8. む す び}

本論文では , オントロジー構築において重要となる

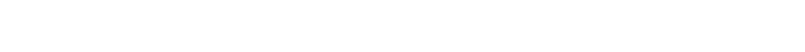
こから得られた知見に基づいて, 設計・開発を行ったオ ントロジー記述環境 (オントロジーエディタ) について 報告した . 特に, 基本概念・ロール概念・ロールホルダー の峻別と, 関係概念と全体概念の対応という2つの理論 に基づいてオントロジーを構筑することを提案し，これ を支援する機能をシステムに実装した点は, 既存研究に 見られない本システムの特徵である .

知識システムを利用する専門家の間では, 自然言語や 図表を用いて表すことの出来ない専門用語の持つ深い意 味や know-how が , 特に実際の運用の場において暗黙裡 に継承されており，これらの暗黙的な知識の全てをオン トロジーを用いて明示化することは困難である．しかし， これらの専門家が持つ暗黙的な知識を継承する能力を前 提にすれば , オントロジーに基づくモデルや知識ベース 構築, タスクの実行・支援などは, 彼らが互いに合意す るための手段として十分に有効であると思われる．実際， 本研究で開発されたオントロジーエディタは, 既に樣々 なオントロジー・モデルの構築に利用されており，元の 有用性が確認されている

今後の課題としては, オントロジーに関する基礎的な 考察をより深める必要があると考えている . 具体的な検 討課題としては，モデル構築時のインスタンス作成支援 方法, オントロジー工学基礎論 [溝口 99b] で述べられて いる 7 種類の part-of 関係の扱い, 本論文で述べた以外 のロール概念の分類と組織化などがあげられる . ロール 概念に関する理解を深めることで, コンテクストに応じ た知識の視点を管理・変換する枠組みを提供することが 可能になると期待されている .

一方，本論文で述べたように詳細なオントロジーの記 述を行うことで，オントロジーを構築するユーザーの負 担が大きくなるという問題も生じる . このような問題に

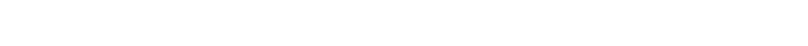
ている . 1つはオントロジー構築を支援するガイドライ ンや方法論，およびそれを実装したガイドシステムの開 発で，「概念工房」が光れに当たる．また产の一方で，記 述環境で扱うオントロジーの詳細度を，ユーザーの熟練 度に応じて段階的に切り替える枠組みについても検討し ている.いづれにしても，オントロジーの詳細度と構築 コストの兼ね合いは, 極めて難しい問題で, 樣々な開発
経験を通して長期的・継続的に検討を重ねていかねばな らない問題である.

\section{謝辞}

本研究は科学研究費補助金 (基盤研究 (B)(2)11480076) オントロジーの基礎理論と光の開発環境に関する研究 の 援助のもとでなされた．また査読者から極めて有意義な コメントをいただいたことに感謝します．

\section{$\diamond$ 参 考 文 献 $\diamond$}

[Barros 01] Barros, B., Mizoguchi, R., and Verdejo, F.: A Platform for Collaboration Analysis in CSCL. An ontological approach, in Proceedings of AIED01, St. Antonio, USA (to appear,2001).

[Barwise 83] Barwise, J. and Perry, J.: Situations and Attitudes, MIT Press (1983).

[Domingue 98] Domingue, J.: Tadzebao and WebOnto: Discussing, Browsing, and Editing Ontologies on the Web, Proceedings of the 11th Banff Knowledge Acquisition Workshop. (1998).

[Farquhar 96] Farquhar, A., Fikes, R., and Rice, J.: The Ontolingua Server: a Tool for Collaborative Ontology Construction, Proceedings of the 10th Banff Knowledge Acquisition Workshop (1996).

[Guarino 98] Guarino, N.: Some Ontological Principles for Designing Upper Level Lexical Resources, International Conference on Lexical Resources and Evaluation (1998).

[林 98] 林, 瀬田, 池田, 金, 角所, 溝口 : 概念間関係に関するオン トロジー的考察〜is-a , part-of , identity〜，信学技報 AI98-40, pp. 1-8 (1998).

[石川 02] 石川, 久保, 古崎, 來村, 溝口 : タスク・ドメインロール に基づくオントロジー構築ガイドシステムの設計と開発 - 石油 精製プラントを例として - , 人工知能学会誌 (投稿中) (2002).

[金 99] 金, 林, 池田, 溝口 他: 訓練システム SmartTrainer 構築 用オーサリングツール, 教育情報学会学会誌秋号, Vol. 16, No. 3, pp. 139-148 (1999).

[來村 02] 來村, 笠井, 吉川, 高橋, 古崎, 溝口 : オントロジーに基 づく機能的知識の体系的記述と炎の機能構造設計支援における 利用, 人工知能学論文会誌, Vol. 17, No. 1, pp. 73-84 (2002).

[古崎 99a] 古崎, 久保, 來村, 池田, 溝口 : オントロジー構築利用 環境「法造」の設計と試作, 人工知能学会全国大会論文集 (第 13 回), pp. 374-377 (1999).

[古崎 99b] 古崎, 久保, 來村, 池田, 溝口 : オントロジー構築利 用環境の開発〜「関係」および「ロール概念」に関する基礎的 考察〜, 人工知能学会研究会資料 SIG-KBS-9803, pp. 13-18 (1999).

[古崎 02] 古崎, 來村, 佐野, 本松, 石川, 溝口 : オントロジー構 築・利用環境「法造」の開発と利用 - 実規模プラントオントロ ジーを例として - 人工知能学会論文誌 (投稿中) (2002).

[久保 98] 久保, 古崎, 來村, 池田, 溝口 : オントロジー構筑ガイド システムの概念設計, 人工知能学会全国大会論文集 (第 12 回), pp. 36-39 (1998).

[久保 99] 久保, 古崎, 來村, 溝口 : オントロジー構築方法 AFM(Activity-First Method) の詳細化の試み, 人工知能学会 全国大会論文集（第 13 回），pp. 114-117 (1999).

[Mahalingam 99] Mahalingam, K. and Huhns, M. Java Ontology Editor (JOE) TUTORIAL (1999), http://www.engr.sc.edu/research/CIT/demos/java/joe/.

[Mizoguchi 95] Mizoguchi, R., Ikeda, M., Seta, K., and Vanwelkenhuysen, J.: Ontology for Modeling the World from Problem Solving Perspectives, in IJCAI Workshop on Basic Ontological Issues in Knowledge Sharing (1995).

[溝口 99a] 溝口理一郎: オントロジー研究の基礎と応用, 人工知 能学会誌, Vol. 14, No. 6, pp. 977-988 (1999).

[溝口 99b] 溝口, 池田, 來村 : オントロジー工学基礎論, 人工知 
能学会誌, Vol. 14, No. 6, pp. 1019-1032 (1999).

[Noy 01] Noy, N. F., Sintek, M., Decker, S., Crubezy, M., Fergerson, R. W., and Musen, M. A.: Creating Semantic Web Contents with Protégé-2000, IEEE Intelligent Systems, pp. 60-71 (2001).

[佐野 99] 佐野, 來村, 溝口 : ヒューマンメディア・プロジェクト における石油プラントオントロジーの構築と光の利用, 人工知 能学会全国大会論文集 (第 13 回)，pp. 378-381 (1999).

[Staab 00] Staab, S. and Maedche, A.: Ontology Engineering beyond the Modeling of Concepts and Relations, Koblenz, Germany (2000).

[Swartout 96] Swartout, B., Patil, R., Knight, K., and Russ, T.: Toward Distributed Use of Large-Scale Ontologies, Proceedings of the 10th Banff Knowledge Acquisition Workshop (1996).

[鷹合 97] 鷹合, 武田, 西田 他 : オントロジーを用いた設計者の 統合支援環境, 人工知能学会全国大会論文集 (第 11 回) , pp 569-572 (1997).

[高岡 95] 高岡, 広部, 溝口 : 再利用可能知識ベースの構築, 人工 知能学会誌, Vol. 10, No. 5, pp. 786-797 (1995).

[Takaoka 96] Takaoka, Y. and Mizoguchi, R.: Identification of Ontologies to Reuse Knowledge for Substation Fault Recovery Support System, Decision Support Systems 18, pp. 3-21 (1996).

〔担当委員 : 木下哲男〕

2001 年 4 月 27 日 受理

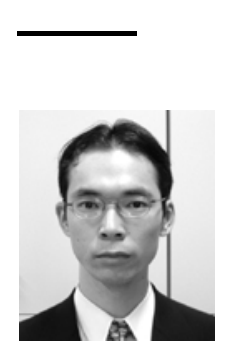

\section{紹 介}

古崎 晃司(学生会員)

1997 年大阪大学工学部電子工学科卒業. 現在同大学院工 学研究科博士後期課程在学中.オントロジー工学の基礎理 論，オントロジー構築環境，Web 情報システムに関する 研究に興味を持つ. 情報処理学会会員 .

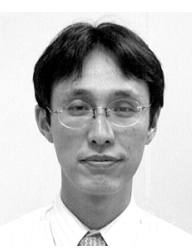

來村 徳信(正会員)

1991 年大阪大学基礎工学部情報工学科卒業. 1993 年同 大学院基礎工学研究科前期課程修了. 同年, 同大学産業技 術研究所技官. 1994 年同助手. 現在に至る. 博士 (工学) . 物理的システムに関するオントロジー工学的考察と, 弚れ に基づいたモデル化と推論に関する研究に従事.1996 年 人工知能学会創立 10 周年記念論文賞受賞 . 情報処理学会 会員

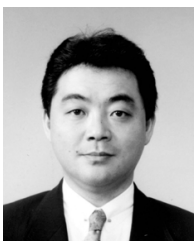

\section{池田＼cjkstart満(正会員)}

1984 年宇都宮大学工学部卒同大学. 1986 年院修士課程 了大阪大学大学院博士. 1989 年課程了. 同年宇都宮大学 助手. 1991 年大阪大学産業科学研究所助手. 1997 年同 助教授、工学博士、形式言語の構文解析，仮説推論，帰納 推論, 知的教育システム, オントロジー工学の研究に従事 人工知能学会設立 10 周年記念優秀論文賞受賞 . 人工知能 学会, 電子情報通信学会, 情報処理学会, 教育システム情 報学会各会員.

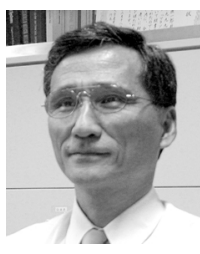

溝口 理一郎(正会員)

1977 年同大学院基礎工学研究科博士課程修了. 1978 年大 阪大学産業科学研究所助手, 1987 年同研究所助教授, 1990 年同教授、現在に至る.工学博士. 音声の認識・理解、エキ スパートシステム, 知的 CAI システム, オントロジー工学 の研究に従事. 1985 年 Pattern Recognition Society 論文賞, 1988 年電子情報通信学会論文賞, 1996 年人工知 能学会創立 10 周年記念論文賞, 1999 年 ICCE99 Best paper Award 受賞. 電子情報通信学会, 情報処理学会, 教育システム情報学会，日本認知科学会，Intl. AI in Education(IAIED) Soc., AAAI, IEEE , APC of AACE 各会員. 現在, IAIED Soc. 会長, 及び APC of AACE の次期会長 . 